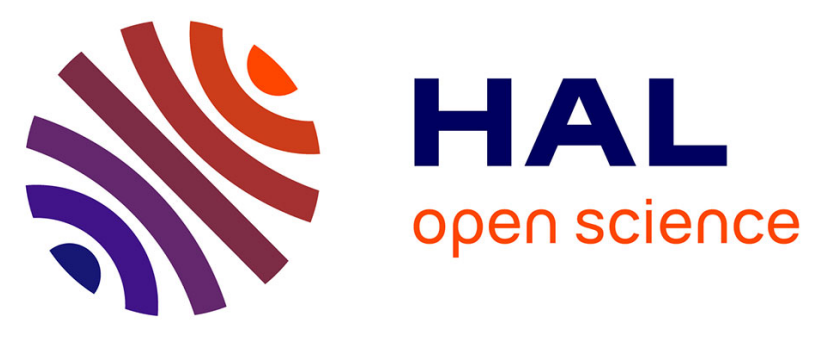

\title{
Clara Cell Protein in Full-term Pregnancies: The Influence of Intrauterine Growth Restriction
}

Despina D Briana, Dimitrios Gourgiotis, Maria Boutsikou, Stavroula Baka, Antonios Marmarinos, Sofia Liosi, Dimitrios Hassiakos, Ariadne Malamitsi-Puchner

\section{To cite this version:}

Despina D Briana, Dimitrios Gourgiotis, Maria Boutsikou, Stavroula Baka, Antonios Marmarinos, et al.. Clara Cell Protein in Full-term Pregnancies: The Influence of Intrauterine Growth Restriction. Pediatric Pulmonology, 2010, 45 (12), pp.1186. 10.1002/ppul.21305 . hal-00566723

\section{HAL Id: hal-00566723 https://hal.science/hal-00566723}

Submitted on 17 Feb 2011

HAL is a multi-disciplinary open access archive for the deposit and dissemination of scientific research documents, whether they are published or not. The documents may come from teaching and research institutions in France or abroad, or from public or private research centers.
L'archive ouverte pluridisciplinaire HAL, est destinée au dépôt et à la diffusion de documents scientifiques de niveau recherche, publiés ou non, émanant des établissements d'enseignement et de recherche français ou étrangers, des laboratoires publics ou privés. 


\section{Clara Cell Protein in Full-term Pregnancies: The Influence of Intrauterine Growth Restriction}

\begin{tabular}{|c|c|}
\hline Journal: & Pediatric Pulmonology \\
\hline Manuscript ID: & PPUL-09-0400.R2 \\
\hline Wiley - Manuscript type: & Original Article \\
\hline $\begin{array}{r}\text { Date Submitted by the } \\
\text { Author: }\end{array}$ & 13-Apr-2010 \\
\hline Complete List of Authors: & $\begin{array}{l}\text { Briana, Despina; Athens University Medical School } \\
\text { Gourgiotis, Dimitrios; Athens University Medical School } \\
\text { Boutsikou, Maria; Athens University Medical School } \\
\text { Baka, Stavroula; Athens University Medical School } \\
\text { Marmarinos, Antonios; Athens University Medical School } \\
\text { Liosi, Sofia; Athens University Medical School } \\
\text { Hassiakos, Dimitrios; Athens University Medical School } \\
\text { Malamitsi-Puchner, Ariadne; Athens University Medical School }\end{array}$ \\
\hline Keywords: & $\begin{array}{l}\text { Clara cell protein, lung, intrauterine growth restriction, fetus, } \\
\text { neonate }\end{array}$ \\
\hline
\end{tabular}

\section{scholarONE" \\ Manuscript Central}




\title{
Clara Cell Protein in Full-term Pregnancies: The Influence
}

\section{of Intrauterine Growth Restriction}

\author{
Despina D. Briana MD', Dimitrios Gourgiotis $\mathrm{PhD}^{2}$, Maria Boutsikou MD¹, \\ Stavroula Baka MD ${ }^{1}$, Antonios Marmarinos $\mathrm{PhD}^{2}$, Sofia Liosi MD , Dimitrios \\ Hassiakos MD', Ariadne Malamitsi-Puchner MD $^{1}$ \\ ${ }^{1}$ Second Department of Obstetrics and Gynecology, Athens University Medical \\ School, Athens, Greece \\ ${ }^{2}$ Research Laboratories, $2^{\text {nd }}$ Department of Pediatrics, Athens University Medical \\ School, Athens, Greece
}

The authors indicate they have no financial relationships relevant to this article to disclose

Corresponding author:

Ariadne Malamitsi-Puchner, MD

19, Soultani Street,

10682 Athens, Greece

Tel: +30 6944443815

Fax: + 302107233330

E-mail address: amalpu@ aretaieio.uoa.gr, amalpu@otenet.gr

Short title: Clara cell protein in IUGR 


\section{Summary}

Background: Clara cell protein (CC16) is an immunomodulatory/anti-inflammatory broncho-alveolar-derived molecule and a biomarker of pulmonary epithelial cells maturity and alveolo-capillary membrane injury. Intrauterine-growth-restricted(IUGR) neonates may present with structural lung immaturity, impaired immunocompetence and increased risk for respiratory infections and chronic obstructive lung disease in later life. Objectives: To investigate circulating CC16 concentrations in maternal, fetal and neonatal samples from IUGR and appropriatefor-gestational-age-(AGA) pregnancies. Methods: Serum CC16 concentrations were determined by EIA in 40 mothers and their 20 IUGR and 20 AGA singleton full-term fetuses-neonates on postnatal day 1-(N1) and 4-(N4). Results: No significant differences in CC16 concentrations were observed between IUGR and AGA groups. In both groups, maternal CC16 concentrations were lower compared to N1 and N4 ones $(P<0.001$ in each case $)$. Fetal CC16 concentrations were significantly lower compared to $\mathrm{N} 1$ and $\mathrm{N} 4$ ones $(P<0.001$ in each case $)$. In the AGA group, N1 CC16 concentrations were significantly higher than N4 ones $(P<0.001)$. Combining groups, N1 CC16 concentrations positively correlated with gestational age $(r=0.364$, $P=0.021)$. Finally, the effect of gender, parity and maternal age on CC16 concentrations was not significant. Conclusions: The lack of differences in CC16 concentrations between IUGR and AGA groups possibly suggests that the lung immaturity and later respiratory diseases, associated with the former, may not be related to early CC16 deficiency. CC16 concentrations increase with advancing gestational age and peak on the first day of life, possibly indicating a vital role of the protein in fetal lung maturation and extrauterine pulmonary adaptation.

Key words: Clara cell protein, lung, intrauterine growth restriction, fetus, neonate 


\section{Introduction}

Clara cell protein (known as CC16, CCSP, CC10 or uteroglobin), one of the major secretory proteins of the lungs, is produced by the nonciliated Clara cells, lining the bronchial and bronchiolar epithelium. ${ }^{1} \mathrm{CC} 16$ has been implicated in fetal lung growth $^{2}$ and has been ascribed many anti-inflammatory/immunomodulatory properties, including inhibition of pro-inflammatory cytokine production and neutrophil infiltration. ${ }^{1,3,4}$ Thus, CC16 prevents and ameliorates lung injury in adult mice and humans ${ }^{5,6}$ and protects the respiratory tract from life-threatening immunological reactions elicited by infectious agents. ${ }^{3,6}$

CC16 concentrations in bronchoalveolar lavage fluid (BALF) depend on the number and integrity of Clara cells. ${ }^{1}$ BALF CC16 concentrations are increased in patients with respiratory distress syndrome and decreased in patients with chronic obstructive pulmonary disease and idiopathic pulmonary fibrosis. ${ }^{4,7,8}$ On the other hand, serum CC16 concentrations reflect alveolo-capillary membrane permeability. ${ }^{4}$ Lower serum CC16 concentrations have been detected in adults with chronic obstructive pulmonary disease, ${ }^{9}$ in children with asthma ${ }^{10}$ and preterm neonates with respiratory distress and bronchopulmonary dysplasia. ${ }^{11,12}$ Furthermore, serum CC16 is considered a sensitive and specific marker of lung injury in adults. ${ }^{1,4,9}$

Recent epidemiological and experimental evidence in humans and animals indicates that the lung can be detrimentally affected by an adverse intrauterine environment, resulting in persistent alterations in lung structure and impaired respiratory function during postnatal life. ${ }^{13}$ In this respect, intrauterine growth restriction (IUGR) has been associated with respiratory compromise and higher incidence of lower respiratory tract infections and chronic obstructive airway disease in later life. ${ }^{14-16}$ However, data 
assessing the impact of IUGR on fetal lung development are limited and predominantly derive from animal experimentation. ${ }^{17-19}$

This study was based on the hypothesis that circulating CC16 concentrations may differ between IUGR and appropriate for gestational age (AGA) fetuses and neonates, since the former may present with structural lung immaturity, impaired immunocompetence and increased risk for developing respiratory infections and chronic obstructive lung disease in later life. ${ }^{14-20}$ Therefore, we aimed to investigate, for the first time to our knowledge, serum CC16 concentrations in IUGR and AGA pregnancies at crucial perinatal time-points and correlate them with several maternal and fetal anthropometric/clinical variables. 


\section{Materials and Methods}

The Ethics Committee of our teaching hospital approved the study protocol. All included mothers provided signed informed consent before recruitment. Forty parturients giving consecutively birth, either to 20 AGA or 20 asymmetric IUGR fullterm singleton infants (birth weight $\leq 5^{\text {th }}$ customized centile) were included in the study. The Gestation Related Optimal Weight computer-generated program ${ }^{21}$ was used to calculate the customized centile for each pregnancy, taking into consideration significant determinants of birth weight, such as maternal height and booking weight, ethnic group, parity, gestational age and gender. ${ }^{21}$ Gestational age was estimated using the date of the last menstrual period and early antenatal ultrasound. Birth weight was measured with an electronic scale.

Ten of the 20 mothers with IUGR offspring were smoking $>10$ cigarettes/day during the whole duration of pregnancy. The remaining 10 mothers presented with preeclampsia $^{22}$ (6 cases), hypothyroidism (2 cases), iron-deficient anemia (1 case), and gestational diabetes mellitus (1 case).

Doppler studies were performed in the IUGR group every 10-15 days, starting from the $32^{\text {nd }}$ gestational week. During each Doppler velocimetry evaluation, three consecutive measurements of the pulsatility index (PI) of the studied vessel (uterine, umbilical, cerebral arteries) were done and the mean value was recorded. Concerning uterine and umbilical arteries, ${ }^{23,24}$ mean PI values were progressively found to be in the upper physiological limits for the corresponding gestational age in 10 cases (ranging between the $90^{\text {th }}$ and the $95^{\text {th }}$ percentile), while in the remaining 10 cases PI values showed increased impedance to flow, being above the $95^{\text {th }}$ percentile for gestational age. Regarding middle cerebral arteries, ${ }^{25}$ Doppler studies showed resistance to be in the lower physiological limits for gestational age, indicating the 
initiation of blood flow redistribution process, in order to spare vital organs (brain, heart and adrenals). Nevertheless, amniotic fluid was diminished in all IUGR cases. For the evaluation of the amniotic fluid, the largest fluid column on the vertical plane was assessed and was defined as diminished, if $<2 \mathrm{~cm}$. Placental weights were reduced ${ }^{26}$ ranging from 240 to $450 \mathrm{~g}$.

In the AGA group, mothers were healthy and were either non-smokers or abstained from smoking during pregnancy. Placentas were normal in appearance and weight. ${ }^{26}$ Tests for congenital infections were negative in all women of both groups, and their offspring had no symptoms of intrauterine infection or signs of genetic syndromes. One- and five-minute Apgar scores were in all cases and controls $\geq 8$. All neonates were breastfed. Demographic data of participating subjects are listed in Table 1.

Blood was collected in pyrogen-free tubes from: i) the mothers during the first stage of labor, or before receiving anesthesia in cases of elective caesarean section ii) the umbilical cords after double clamping, reflecting fetal state, and iii) the neonates before feeding on postpartum day $1(\mathrm{~N} 1)$ and $4(\mathrm{~N} 4)$, characterizing transition and stabilization to extrauterine life, respectively. Serum was separated by centrifugation after clotting and was kept frozen at $-80^{\circ} \mathrm{C}$ until assay.

The determination of serum CC16 concentrations was performed by enzyme immunoassay (EIA) (Biovendor, GmbH, 69120 Heiderberg, Germany). The minimum detectable concentration, intra- and interassay coefficients of variation were 20 $\mathrm{pg} / \mathrm{mL}, 5.7 \%$ and $4.1 \%$, respectively.

\section{Statistical analysis}

CC16 data were normally distributed (Kolmogorov- Smirnov test); thus, parametric tests (Anova for repeated measures, paired samples t-test with Bonferroni correction for multiple comparisons) were applied in the analysis. Spearman's or Pearson's 
correlation coefficient, where appropriate, were used to detect any positive or negative correlations. A $P<0.05$ was considered statistically significant. 


\section{Results}

Determined circulating CC16 values are shown in Table 2 (mean \pm SD), as well as in Figure 1 (mean, [95\% confidence intervals]). No significant differences in CC16 concentrations were observed between IUGR cases and AGA controls.

In the AGA group, maternal CC16 concentrations were significantly lower compared to $\mathrm{N} 1$ and $\mathrm{N} 4$ ones $(P<0.001$ and $P=0.004$, respectively). Fetal CC16 concentrations were significantly lower compared to N1 and N4 ones ( $P=0.001$ in each case), while N1 CC16 concentrations were significantly higher compared to N4 ones $(P=0.008)$. Fetal CC16 concentrations positively correlated with N1 and N4 ones $(r=0.619$, $P=0.004, \quad r=0.680, P=0.001$, respectively). N1 CC16 concentrations positively correlated with N4 ones $(r=0.549, P=0.012)$.

In the IUGR group, maternal CC16 concentrations were significantly lower compared to $\mathrm{N} 1$ and $\mathrm{N} 4$ ones $(P<0.001$ and $P=0.03$, respectively). Fetal CC16 concentrations were significantly lower compared to $\mathrm{N} 1$ and $\mathrm{N} 4 \quad(P<0.001$ and $P=0.005$, respectively) and positively correlated with $\mathrm{N} 1$ and $\mathrm{N} 4$ ones $(r=0.592, P=0.006$ and $r=0.481, P=0.032$, respectively). N1 CC16 concentrations positively correlated with N4 CC16 ones and gestational age $(r=0.585, P=0.007$ and $r=0.510, P=0.022$, respectively).

In a combined group, N1 CC16 concentrations positively correlated with gestational age ( $r=0.364, P=0.021$, respectively). Finally, the effect of infants' customized centiles, gender, parity, maternal age, as well as smoking on CC16 concentrations was not significant in both groups. 


\section{Discussion}

The results of this study indicate a lack of significant differences in serum CC16 concentrations between IUGR cases and AGA controls. Serum CC16 concentrations can be affected by lung CC16 production, as well as by CC16 effusion from the lungs across the alveolo-capillary membrane. ${ }^{1}$ In human adults, BALF CC16 levels correlate well with serum concentrations, and, therefore, the latter have been suggested as a reliable indicator of the total amount of protein synthesized in the

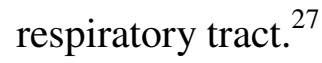

CC16 production seems to be vital in postnatal pulmonary adaptation. However, in animal models, there is no evidence to suggest that the postnatal absorption of lung fluid is dependent on pulmonary perfusion, indicating that lung liquid absorption is dependent on the pulmonary epithelium and not on the pulmonary vasculature. ${ }^{28}$ Furthermore, CC16 plays an important role in the development of lung injury associated with lung maturity. ${ }^{2,11}$ Thus, low cord blood CC16 concentrations in preterm infants $^{12}$, due to reduced production, consequent to Clara cells immaturity, ${ }^{29}$ independently predict the development of bronchopulmonary dysplasia, ${ }^{12}$ while intratracheal administration of recombinant human $\mathrm{CC} 16$ in preterm infants with respiratory distress syndrome reduces the neutrophil counts, which is indicative of CC16 anti-inflammatory properties. ${ }^{30}$ Furthermore, the importance of CC16 as an anti-inflammatory pneumoprotein places neonates with $\mathrm{CC} 16$ deficiency at possible risk of postnatal respiratory injury. ${ }^{11}$

IUGR has been proposed to induce permanent changes in lung structure and pulmonary defense mechanisms. ${ }^{13}$ In this respect, increased incidence of respiratory distress and lower respiratory tract infections has been documented in low birth weight, even full-term, infants. ${ }^{14,31}$ On the other hand, it is well established that stress 
can lead to maturation of the fetal lung, mediated, at least in part, by an increase in fetal cortisol. $^{32}$ Thus, IUGR-characterized by hypercortisolaemia ${ }^{33}$ - has been previously suggested to be associated with enhanced fetal lung maturation. ${ }^{33,34}$ However, this association remains controversial on the basis of human and animal observations, as well as histological data. ${ }^{13,34}$

In this respect, increased amniotic fluid indices of lung maturation have been documented in cases with presumed placental insufficiency. ${ }^{34}$ However, prolonged intrauterine exposure to glucocorticoids in IUGR could have an inhibitory effect on alveolar formation, resulting in an emphysematous state of the lung. ${ }^{35}$ Moreover, in a series of studies, the lungs of IUGR fetuses appeared to be structurally impaired ${ }^{13}$ with reduced weight, DNA and protein content, ${ }^{36}$ and immature alveolar wall and airblood barrier. ${ }^{37}$ Nevertheless, in our study, the lack of differences in CC16 concentrations between IUGR cases and AGA controls possibly assumes that the lung immaturity and later respiratory diseases associated with the former may not be related to early CC16 deficiency.

This study confirms the presence of a gestational influence on CC16 production, which has also been suggested by previous reports concerning amniotic fluid, ${ }^{2,38}$ BALF of mechanically ventilated preterm neonates ${ }^{39}$ and umbilical cord blood of both preterm and term infants. ${ }^{11} \mathrm{CC} 16$ is detectable in amniotic fluid from the $15^{\text {th }}$ week of gestation $^{2}$ and increases with advancing gestational age, possibly due to continuous fetal CC16 production, secondary to fetal airway growth and/or lung maturation., ${ }^{2,38}$

Furthermore, in accordance with a previous report, ${ }^{11}$ our results indicate that serum CC16 concentrations peak on the first day of life. This production surge at birth has been demonstrated to be more pronounced in term compared to preterm infants, conferring the former with superior extrauterine pulmonary protection. ${ }^{11}$ Thus, term 
infants who are better equipped for extrauterine life had highest serum and lung fluid CC16 on day 1 , indicating that $\mathrm{CC} 16$ production at birth may be an important part of postnatal adaptation. ${ }^{11}$

Additionally, our data suggest that neonatal CC16 concentrations are higher than maternal ones. Similarly, a recent study demonstrated increased CC16 concentrations in newborns compared to healthy adults. ${ }^{11}$ Such concentrations may be necessary for postnatal lung adaptation.

Furthermore, we were not able to confirm the reported circadian alterations of serum CC16, with on average a $20 \%$ decrease at the end of the day. ${ }^{40}$

Finally, the absence of a gender effect in circulating CC16 concentrations is in line with previous reports in healthy adults. ${ }^{41,42}$

In conclusion, circulating CC16 concentrations are similar between IUGR and AGA groups, possibly suggesting that the lung immaturity and later respiratory diseases associated with the former may not be related to early CC16 deficiency. Moreover, serum CC16 concentrations increase with increasing gestational age and peak on the first day of life, possibly indicating a vital role of this protein in fetal lung maturation and extrauterine pulmonary adaptation, respectively. Future research is necessary to elucidate the role of $\mathrm{CC} 16$ in fetal lung development and postnatal respiratory adaptation in both normal and complicated pregnancies. 


\section{Acknowledgments}

No conflict of interest is declared. 


\section{References}

1. Broeckaert F, Clippe A, Knoops B, Hermans C, Bernard A. Clara cell secretory protein (CC16): features as a peripheral lung biomarker. Ann N Y Acad Sci 2000;923:68-77.

2. Bernard A, Thielemans N, Lauwerys R, Langhendries JP, Van Lierde M, Freud MM. Clara cell protein in human amniotic fluid: a potential marker of fetal lung growth. Pediatr Res 1994;36:771-775.

3. Harrod KS, Mounday AD, Stripp BR, Whitsett JA. Clara cell secretory protein decreases lung inflammation after acute virus infection. Am J Physiol 1998;275:L924-L930.

4. Hermans C, Knoops B, Wiedig M, Arsalane K, Toubeau G, Falmagne P, Bernard A. Clara cell protein as a marker of Clara cell damage and bronchoalveolar blood barrier permeability. Eur Respir J 1999;13:1014-1021.

5. Watson TM, Reynolds SD, Mango GW, Boe IM, Lund J, Stripp BR. Altered lung gene expression in CCSP-null mice suggests immunoregulatory roles for Clara cells. Am J Physiol Lung Cell Mol Physiol 2001;281:L1523:L1530.

6. Dierynck I, Bernard A, Roels H, De Ley M. Potent inhibition of both human interferon-gamma production and biological activity by the Clara cell protein CC16. Am J Respir Cell Moll Biol 1995;12:205-210.

7. Hermans C, Bernard A. Lung epithelium-specific proteins: characteristics and potential applications as markers. Am J Respir Crit Care Med 1999;159:646678.

8. Johnston CJ, Mango GW, Finkelstein JN, Stripp BR. Altered pulmonary response to hyperoxia in Clara cell secretory protein deficient mice. Am J Respir Cell Moll Biol 1997;17:147-155. 
9. Lomas DA, Silverman EK, Edwards LD, Miller BE, Coxson HO, Tal-Singer R; Evaluation of COPD Longitudinally to identify Predictive Surrogate Endpoints (ECLIPSE) investigators. Evaluation of serum $\mathrm{CC}-16$ as a biomarker for COPD in the ECLIPSE cohort. Thorax 2008;63:1058-1063.

10. Gioldassi XM, Papadimitriou H, Mikraki V, Karamanos NK. Clara cell secretory protein: determination of serum levels by an enzyme immunoassay and its importance as an indicator of bronchial asthma in children. J Pharm Biomed Anal 2004;34:823-826.

11. Loughran-Fowlds A, Oei J, Wang $\mathrm{H}, \mathrm{Xu} \mathrm{H}$, Wimalasundera $\mathrm{N}$, Egan $\mathrm{C}$, Henry R, Lui K. The influence of gestation and mechanical ventilation on serum clara cell secretory protein $(\mathrm{CC} 10)$ concentrations in ventilated and nonventilated newborn infants. Pediatr Res 2006;60:103-108.

12. Schrama AJ, Bernard A, Poorthuis BJ, Zwinderman AH, Berger HM, Walther FJ. Cord blood Clara cell protein CC16 predicts the development of bronchopulmonary dysplasia. Eur J Pediatr 2008;167:1305-1312.

13. Harding R, Cock ML, Louey S, Joyce BJ, Davey MG, Albuquerque CA, Hooper SB, Maritz GS. The compromised intra-uterine environment: implications for future lung health. Clin Exp Pharmacol Physiol 2000;27:965974.

14. Barker DJ, Godfrey KM, Fall C, Osmond C, Winter PD, Shaheen SO. Relation of birth weight and childhood respiratory infection to adult lung function and death from chronic obstructive airway disease. BMJ 1991;303:671-675. 
15. Rona RJ, Gulliford MC, Chinn S. Effects of Prematurity and intrauterine growth on respiratory health and lung function in childhood. BMJ 1993;306:817-820.

16. Canoy D, Pekkanen J, Elliott P, Pouta A, Laitinen J, Hartikainen AL, Zitting P, Patel S, Little MP, Jarvelin MR. Early growth and adult respiratory function in men and women followed from the fetal period to adulthood. Thorax 2007;62:396-402.

17. Cock ML, Albuquerque CA, Joyce BJ, Hooper SB, Harding R. Effects of intrauterine growth restriction on lung liquid dynamics and lung development in fetal sheep. Am J Obstet Gynecol 2001;184:209-216.

18. Maritz GS, Cock ML, Louey S, Joyce BJ, Albuquerque CA, Harding R. Effects of fetal growth restriction on lung development before and after birth: a morphometric analysis. Pediatr Pulmonol 2001;32:201-210.

19. Chen CM, Wang LF, Su B. Effects of maternal undernutrition during late gestation on the lung surfactant system and morphometry in rats. Pediatr Res 2004;56:329-335.

20. Ferguson AC. Prolonged impairment of cellular immunity in children with intrauterine growth retardation. J Pediatr 1978;93:52-56.

21. Gardosi J, Chang A, Kaylan B, Sahota D, Symonds EM. Customised antenatal growth charts. Lancet 1992;339:283-287.

22. CLASP (Collaborative Low-dose Aspirin Study in Pregnancy) Collaborative Group. CLASP: a randomised trial of low-dose aspirin for the prevention and treatment of pre-eclampsia among 9364 pregnant women. Lancet 1994:343:619-629. 
23. Burkhardt T, Schaffer L, Schneider C, Zimmermann R, Kurmanavicious J. Reference values for the weight of freshly delivered term placentas and for placental weight-birth weight ratios. Eur J Obstet Gynecol Reprod Biol 2006;128:248-252.

24. Kaminopetros P, Higueras MT, Nicolaides KH. Doppler study of uterine artery blood flow: comparison of findings in the first and second trimesters of pregnancy. Fetal Diagn Ther 1991;6:58-64.

25. Acharya G, Wilsgaard T, Berntsen GK, Maltau JM, Kiserud T. Reference ranges for serial measurements of umbilical artery Doppler indices in the second half of pregnancy. Am J Obstet Gynecol 2005;192:937-944.

26. Baschat AA, Galan HL, Bhide A, Berg C, Kush ML, Oepkes D. Doppler and biophysical assessment in growth restricted fetuses: distribution of test results. Ultrasound Obstet Gynecol 2006;27:41-47.

27. Bernard A, Marchandise FX, Depelchin S, Lauwerys R, Sibille Y. Clara cell protein in serum and bronchoalveolar lavage. Eur Respir J 1992;5:1231-1238.

28. Junor RW, Benjamin AR, Alexandrou D, Walters DV. The independence of lung liquid absorption in postnatal sheep on pulmonary blood flow, blood gases or perfussion pressure. Exp Physiol 2001;86:391-398.

29. Lassus P, Nevalainen TJ, Eskola JU, Andersson S. Clara-cell secretory protein in preterm infants' tracheal aspirates correlates with maturity and increases in infection. Pediatr Pulmonol 2000;30:466-469.

30. Levine CR, Gewolb IH, Allen K, Welch RW, Melby JM, Pollack S, Shaffer T, Pilon AL, Davis JM. The safety, pharmacokinetics, and anti-inflammatory effects of intratracheal recombinant human Clara cell protein in premature infants with respiratory distress syndrome. Pediatr Res 2005;58:15-21. 
31. Piazze JJ, Anceschi MM, Picone G, Cerekja A, La Torre R, Cosmi EV. Association between maternal-fetal Doppler velocimetry and fetal lung maturity. J Perinat Med 2003;31:484-488.

32. Ballard PL, Ballard RA. Scientific basis and therapeutic regimens for use of antenatal glucocorticoids. Am J Obstet Gynecol 1995;173:254-262.

33. Seckl JR. Glucocorticoid programming of the fetus: adult phenotypes and molecular mechanisms. Mol Cell Endocrinol 2001;185:61-71.

34. Torrance HL, Voorbij HA, Wijnberger LD, van Bel F, Visser GH. Lung maturation in small for gestational age fetuses from pregnancies complicated by placental insufficiency or maternal hypertension. Early Hum Dev 2008;84:465-469.

35. Jobe AH. Glucocorticoids, inflammation and the perinatal lung. Semin Neonatol 2001;6:331-342.

36. Sahebjami H, MacGee J. Effects of starvation on lung mechanics and biochemistry in young and old rats. J Appl Physiol 1985;58:778-784.

37. Das RM. The effects of intermittent starvation on lung development in suckling rats. Am J Pathol 1984;117:326-332.

38. Maturana A, Bernard A, Germain AM, Chau VL, Moya FR. Amniotic fluid Clara cell protein concentration in normal pregnancy, a marker of fetal airway growth or fetal lung maturation? J Perinatol 2001;21:516-520.

39. Lassus P, Nevalainen TJ, Eskola JU, Andersson S. Clara-cell secretory protein in preterm infants' tracheal aspirates correlates with maturity and increases in infection. Pediatr Pulmonol 2000;30:466-469. 
40. Helledey R, Segerstedt B, Forsberg B, Mudway I, Nordberg G, Bernard A, Blomberg A. Exploring the time dependence of serum clara cell protein as a biomarker of pulmonary injury in humans. Chest 2006;130:672-675.

41. De Jongh R, Vranken J, Kenis G, Bosmans E, Maes M, Stans G, De Ley M, Heylen R. Clara cell protein: concentrations in cerebrospinal fluid, serum and amniotic fluid. Cytokine 1998;10:441-444.

42. Nomori H, Horio H, Fuyuno G, Kobayashi R, Morigana S, Hirabayashi Y. Protein 1 (Clara cell protein) serum levels in healthy subjects and patients with bacterial pneumonia. Am J Respir Crit Care Med 1995;152:746-750. 
Table 1. Demographic data for AGA and IUGR neonates and their mothers

\begin{tabular}{|c|c|c|c|}
\hline & AGA & IUGR & $P$ \\
\hline & Mean (SD) & Mean (SD) & \\
\hline Birthweight (g) & $3280(333)$ & $2511(261)$ & $<0.001$ \\
\hline Birthweight centile & $46(24.7)$ & $2.95(1.9)$ & $<0.001$ \\
\hline Gestational age (weeks) & $39.2(0.83)$ & $38.5(1.2)$ & NS \\
\hline Gender & & & NS \\
\hline Male & $10(50 \%)$ & $7(35 \%)$ & \\
\hline Female & $10(50 \%)$ & $13(65 \%)$ & \\
\hline Maternal age (years) & $30(4.8)$ & $32.7(4.3)$ & NS \\
\hline Parity & & & NS \\
\hline Primigravida & $14(70 \%)$ & $11(55 \%)$ & \\
\hline Other & $6(30 \%)$ & $9(45 \%)$ & \\
\hline Mode of delivery & & & NS \\
\hline Vaginal & $15(75 \%)$ & $10(50 \%)$ & \\
\hline Cesarean section & $5(25 \%)$ & $10(50 \%)$ & \\
\hline
\end{tabular}

NS: non significant 
Table 2. Mean \pm standard deviation (SD) values $(\mathrm{ng} / \mathrm{ml})$ of CC16 in maternal (MS), fetal (UC), postnatal day 1 (N1) and 4 (N4) serum in appropriate for gestational age (AGA) and intrauterine growth restricted (IUGR) groups.

\begin{tabular}{|l|l|l|l|l|l|}
\hline GROUP & & MS & UC & N1 & N4 \\
\hline AGA & Mean \pm SD & $2.48 \pm 0.53$ & $2.67 \pm 0.58$ & $8.76 \pm 5.98$ & $4.43 \pm 1.97$ \\
\hline IUGR & Mean \pm SD & $2.54 \pm 0.68$ & $2.94 \pm 0.69$ & $7.39 \pm 3.70$ & $5.52 \pm 3.15$ \\
\hline
\end{tabular}


Figure legend

Fig. 1. Mean (95\% CI) serum CC16 concentrations in mothers (MS), fetuses (UC) and neonates on day $1(\mathrm{~N} 1)$ and $4(\mathrm{~N} 4)$ postpartum in appropriate for gestational age (AGA) and intrauterine growth restricted (IUGR) groups. 


\title{
Clara Cell Protein in Full-term Pregnancies: The Influence
}

\section{of Intrauterine Growth Restriction}

\author{
Despina D. Briana MD', Dimitrios Gourgiotis $\mathrm{PhD}^{2}$, Maria Boutsikou MD¹, \\ Stavroula Baka MD ${ }^{1}$, Antonios Marmarinos $\mathrm{PhD}^{2}$, Sofia Liosi MD , Dimitrios \\ Hassiakos MD ${ }^{1}$, Ariadne Malamitsi-Puchner MD $^{1}$ \\ ${ }^{1}$ Second Department of Obstetrics and Gynecology, Athens University Medical \\ School, Athens, Greece \\ ${ }^{2}$ Research Laboratories, $2^{\text {nd }}$ Department of Pediatrics, Athens University Medical \\ School, Athens, Greece
}

The authors indicate they have no financial relationships relevant to this article to disclose

Corresponding author:

Ariadne Malamitsi-Puchner, MD

19, Soultani Street,

10682 Athens, Greece

Tel: +30 6944443815

Fax: + 302107233330

E-mail address: amalpu@ aretaieio.uoa.gr, amalpu@otenet.gr

Short title: Clara cell protein in IUGR 


\section{Summary}

Background: Clara cell protein (CC16) is an immunomodulatory/anti-inflammatory broncho-alveolar-derived molecule and a biomarker of pulmonary epithelial cells maturity and alveolo-capillary membrane injury. Intrauterine-growth-restricted(IUGR) neonates may present with structural lung immaturity, impaired immunocompetence and increased risk for respiratory infections and chronic obstructive lung disease in later life. Objectives: To investigate circulating CC16 concentrations in maternal, fetal and neonatal samples from IUGR and appropriatefor-gestational-age-(AGA) pregnancies. Methods: Serum CC16 concentrations were determined by EIA in 40 mothers and their 20 IUGR and 20 AGA singleton full-term fetuses-neonates on postnatal day 1-(N1) and 4-(N4). Results: No significant differences in CC16 concentrations were observed between IUGR and AGA groups. In both groups, maternal CC16 concentrations were lower compared to N1 and N4 ones $(P<0.001$ in each case). Fetal CC16 concentrations were significantly lower compared to $\mathrm{N} 1$ and $\mathrm{N} 4$ ones $(P<0.001$ in each case $)$. In the AGA group, N1 CC16 concentrations were significantly higher than N4 ones $(P<0.001)$. Combining groups, N1 CC16 concentrations positively correlated with gestational age $(r=0.364$, $P=0.021)$. Finally, the effect of gender, parity and maternal age on CC16 concentrations was not significant. Conclusions: The lack of differences in CC16 concentrations between IUGR and AGA groups possibly suggests that the lung immaturity and later respiratory diseases, associated with the former, may not be related to early CC16 deficiency. CC16 concentrations increase with advancing gestational age and peak on the first day of life, possibly indicating a vital role of the protein in fetal lung maturation and extrauterine pulmonary adaptation.

Key words: Clara cell protein, lung, intrauterine growth restriction, fetus, neonate 


\section{Introduction}

Clara cell protein (known as CC16, CCSP, CC10 or uteroglobin), one of the major secretory proteins of the lungs, is produced by the nonciliated Clara cells, lining the bronchial and bronchiolar epithelium. ${ }^{1} \mathrm{CC} 16$ has been implicated in fetal lung growth $^{2}$ and has been ascribed many anti-inflammatory/immunomodulatory properties, including inhibition of pro-inflammatory cytokine production and neutrophil infiltration. ${ }^{1,3,4}$ Thus, CC16 prevents and ameliorates lung injury in adult mice and humans ${ }^{5,6}$ and protects the respiratory tract from life-threatening immunological reactions elicited by infectious agents. ${ }^{3,6}$

CC16 concentrations in bronchoalveolar lavage fluid (BALF) depend on the number and integrity of Clara cells. ${ }^{1}$ BALF CC16 concentrations are increased in patients with respiratory distress syndrome and decreased in patients with chronic obstructive pulmonary disease and idiopathic pulmonary fibrosis. ${ }^{4,7,8}$ On the other hand, serum CC16 concentrations reflect alveolo-capillary membrane permeability. ${ }^{4}$ Lower serum CC16 concentrations have been detected in adults with chronic obstructive pulmonary disease, ${ }^{9}$ in children with asthma ${ }^{10}$ and preterm neonates with respiratory distress and bronchopulmonary dysplasia. ${ }^{11,12}$ Furthermore, serum CC16 is considered a sensitive and specific marker of lung injury in adults. ${ }^{1,4,9}$

Recent epidemiological and experimental evidence in humans and animals indicates that the lung can be detrimentally affected by an adverse intrauterine environment, resulting in persistent alterations in lung structure and impaired respiratory function during postnatal life. ${ }^{13}$ In this respect, intrauterine growth restriction (IUGR) has been associated with respiratory compromise and higher incidence of lower respiratory tract infections and chronic obstructive airway disease in later life. ${ }^{14-16}$ However, data 
assessing the impact of IUGR on fetal lung development are limited and predominantly derive from animal experimentation. ${ }^{17-19}$

This study was based on the hypothesis that circulating CC16 concentrations may differ between IUGR and appropriate for gestational age (AGA) fetuses and neonates, since the former may present with structural lung immaturity, impaired immunocompetence and increased risk for developing respiratory infections and chronic obstructive lung disease in later life. ${ }^{14-20}$ Therefore, we aimed to investigate, for the first time to our knowledge, serum CC16 concentrations in IUGR and AGA pregnancies at crucial perinatal time-points and correlate them with several maternal and fetal anthropometric/clinical variables. 


\section{Materials and Methods}

The Ethics Committee of our teaching hospital approved the study protocol. All included mothers provided signed informed consent before recruitment. Forty parturients giving consecutively birth, either to 20 AGA or 20 asymmetric IUGR fullterm singleton infants (birth weight $\leq 5^{\text {th }}$ customized centile) were included in the study. The Gestation Related Optimal Weight computer-generated program ${ }^{21}$ was used to calculate the customized centile for each pregnancy, taking into consideration significant determinants of birth weight, such as maternal height and booking weight, ethnic group, parity, gestational age and gender. ${ }^{21}$ Gestational age was estimated using the date of the last menstrual period and early antenatal ultrasound. Birth weight was measured with an electronic scale.

Ten of the 20 mothers with IUGR offspring were smoking $>10$ cigarettes/day during the whole duration of pregnancy. The remaining 10 mothers presented with preeclampsia $^{22}$ (6 cases), hypothyroidism (2 cases), iron-deficient anemia (1 case), and gestational diabetes mellitus (1 case).

Doppler studies were performed in the IUGR group every 10-15 days, starting from the $32^{\text {nd }}$ gestational week. During each Doppler velocimetry evaluation, three consecutive measurements of the pulsatility index (PI) of the studied vessel (uterine, umbilical, cerebral arteries) were done and the mean value was recorded. Concerning uterine and umbilical arteries, ${ }^{23,24}$ mean PI values were progressively found to be in the upper physiological limits for the corresponding gestational age in 10 cases (ranging between the $90^{\text {th }}$ and the $95^{\text {th }}$ percentile), while in the remaining 10 cases PI values showed increased impedance to flow, being above the $95^{\text {th }}$ percentile for gestational age. Regarding middle cerebral arteries, ${ }^{25}$ Doppler studies showed resistance to be in the lower physiological limits for gestational age, indicating the 
initiation of blood flow redistribution process, in order to spare vital organs (brain, heart and adrenals). Nevertheless, amniotic fluid was diminished in all IUGR cases. For the evaluation of the amniotic fluid, the largest fluid column on the vertical plane was assessed and was defined as diminished, if $<2 \mathrm{~cm}$. Placental weights were reduced ${ }^{26}$ ranging from 240 to $450 \mathrm{~g}$.

In the AGA group, mothers were healthy and were either non-smokers or abstained from smoking during pregnancy. Placentas were normal in appearance and weight. ${ }^{26}$ Tests for congenital infections were negative in all women of both groups, and their offspring had no symptoms of intrauterine infection or signs of genetic syndromes. One- and five-minute Apgar scores were in all cases and controls $\geq 8$. All neonates were breastfed. Demographic data of participating subjects are listed in Table 1.

Blood was collected in pyrogen-free tubes from: i) the mothers during the first stage of labor, or before receiving anesthesia in cases of elective caesarean section ii) the umbilical cords after double clamping, reflecting fetal state, and iii) the neonates before feeding on postpartum day $1(\mathrm{~N} 1)$ and $4(\mathrm{~N} 4)$, characterizing transition and stabilization to extrauterine life, respectively. Serum was separated by centrifugation after clotting and was kept frozen at $-80^{\circ} \mathrm{C}$ until assay.

The determination of serum CC16 concentrations was performed by enzyme immunoassay (EIA) (Biovendor, GmbH, 69120 Heiderberg, Germany). The minimum detectable concentration, intra- and interassay coefficients of variation were 20 $\mathrm{pg} / \mathrm{mL}, 5.7 \%$ and $4.1 \%$, respectively.

\section{Statistical analysis}

CC16 data were normally distributed (Kolmogorov- Smirnov test); thus, parametric tests (Anova for repeated measures, paired samples t-test with Bonferroni correction for multiple comparisons) were applied in the analysis. Spearman's or Pearson's 
correlation coefficient, where appropriate, were used to detect any positive or negative correlations. A $P<0.05$ was considered statistically significant. 


\section{Results}

Determined circulating CC16 values are shown in Table 2 (mean \pm SD), as well as in Figure 1 (mean, [95\% confidence intervals]). No significant differences in CC16 concentrations were observed between IUGR cases and AGA controls.

In the AGA group, maternal CC16 concentrations were significantly lower compared to $\mathrm{N} 1$ and $\mathrm{N} 4$ ones $(P<0.001$ and $P=0.004$, respectively). Fetal CC16 concentrations were significantly lower compared to N1 and N4 ones ( $P=0.001$ in each case), while N1 CC16 concentrations were significantly higher compared to N4 ones $(P=0.008)$. Fetal CC16 concentrations positively correlated with N1 and N4 ones $(r=0.619$, $P=0.004, \quad r=0.680, \quad P=0.001$, respectively). N1 CC16 concentrations positively correlated with N4 ones $(r=0.549, P=0.012)$.

In the IUGR group, maternal CC16 concentrations were significantly lower compared to $\mathrm{N} 1$ and $\mathrm{N} 4$ ones $(P<0.001$ and $P=0.03$, respectively). Fetal CC16 concentrations were significantly lower compared to $\mathrm{N} 1$ and $\mathrm{N} 4 \quad(P<0.001$ and $P=0.005$, respectively) and positively correlated with $\mathrm{N} 1$ and $\mathrm{N} 4$ ones $(r=0.592, P=0.006$ and $r=0.481, P=0.032$, respectively). N1 CC16 concentrations positively correlated with N4 CC16 ones and gestational age $(r=0.585, P=0.007$ and $r=0.510, P=0.022$, respectively).

In a combined group, N1 CC16 concentrations positively correlated with gestational age ( $r=0.364, P=0.021$, respectively). Finally, the effect of infants' customized centiles, gender, parity, maternal age, as well as smoking on CC16 concentrations was not significant in both groups. 


\section{Discussion}

The results of this study indicate a lack of significant differences in serum CC16 concentrations between IUGR cases and AGA controls. Serum CC16 concentrations can be affected by lung CC16 production, as well as by CC16 effusion from the lungs across the alveolo-capillary membrane. ${ }^{1}$ In human adults, BALF CC16 levels correlate well with serum concentrations, and, therefore, the latter have been suggested as a reliable indicator of the total amount of protein synthesized in the respiratory tract. $^{27}$

CC16 production seems to be vital in postnatal pulmonary adaptation. However, in animal models, there is no evidence to suggest that the postnatal absorption of lung fluid is dependent on pulmonary perfusion, indicating that lung liquid absorption is dependent on the pulmonary epithelium and not on the pulmonary vasculature. ${ }^{28}$ Furthermore, CC16 plays an important role in the development of lung injury associated with lung maturity. ${ }^{2,11}$ Thus, low cord blood CC16 concentrations in preterm infants $^{12}$, due to reduced production, consequent to Clara cells immaturity, ${ }^{29}$ independently predict the development of bronchopulmonary dysplasia, ${ }^{12}$ while intratracheal administration of recombinant human $\mathrm{CC} 16$ in preterm infants with respiratory distress syndrome reduces the neutrophil counts, which is indicative of CC16 anti-inflammatory properties. ${ }^{30}$ Furthermore, the importance of CC16 as an anti-inflammatory pneumoprotein places neonates with $\mathrm{CC} 16$ deficiency at possible risk of postnatal respiratory injury. ${ }^{11}$

IUGR has been proposed to induce permanent changes in lung structure and pulmonary defense mechanisms. ${ }^{13}$ In this respect, increased incidence of respiratory distress and lower respiratory tract infections has been documented in low birth weight, even full-term, infants. ${ }^{14,31}$ On the other hand, it is well established that stress 
can lead to maturation of the fetal lung, mediated, at least in part, by an increase in fetal cortisol. $^{32}$ Thus, IUGR-characterized by hypercortisolaemia ${ }^{33}$ - has been previously suggested to be associated with enhanced fetal lung maturation. ${ }^{33,34}$ However, this association remains controversial on the basis of human and animal observations, as well as histological data. ${ }^{13,34}$

In this respect, increased amniotic fluid indices of lung maturation have been documented in cases with presumed placental insufficiency. ${ }^{34}$ However, prolonged intrauterine exposure to glucocorticoids in IUGR could have an inhibitory effect on alveolar formation, resulting in an emphysematous state of the lung. ${ }^{35}$ Moreover, in a series of studies, the lungs of IUGR fetuses appeared to be structurally impaired ${ }^{13}$ with reduced weight, DNA and protein content, ${ }^{36}$ and immature alveolar wall and airblood barrier. ${ }^{37}$ Nevertheless, in our study, the lack of differences in CC16 concentrations between IUGR cases and AGA controls possibly assumes that the lung immaturity and later respiratory diseases associated with the former may not be related to early CC16 deficiency.

This study confirms the presence of a gestational influence on CC16 production, which has also been suggested by previous reports concerning amniotic fluid, ${ }^{2,38}$ BALF of mechanically ventilated preterm neonates ${ }^{39}$ and umbilical cord blood of both preterm and term infants. ${ }^{11} \mathrm{CC} 16$ is detectable in amniotic fluid from the $15^{\text {th }}$ week of gestation $^{2}$ and increases with advancing gestational age, possibly due to continuous fetal CC16 production, secondary to fetal airway growth and/or lung maturation. ${ }^{2,38}$

Furthermore, in accordance with a previous report, ${ }^{11}$ our results indicate that serum CC16 concentrations peak on the first day of life. This production surge at birth has been demonstrated to be more pronounced in term compared to preterm infants, conferring the former with superior extrauterine pulmonary protection. ${ }^{11}$ Thus, term 
infants who are better equipped for extrauterine life had highest serum and lung fluid $\mathrm{CC} 16$ on day 1 , indicating that $\mathrm{CC} 16$ production at birth may be an important part of postnatal adaptation. ${ }^{11}$

Additionally, our data suggest that neonatal CC16 concentrations are higher than maternal ones. Similarly, a recent study demonstrated increased CC16 concentrations in newborns compared to healthy adults. ${ }^{11}$ Such concentrations may be necessary for postnatal lung adaptation.

Furthermore, we were not able to confirm the reported circadian alterations of serum CC16, with on average a $20 \%$ decrease at the end of the day. ${ }^{40}$

Finally, the absence of a gender effect in circulating CC16 concentrations is in line with previous reports in healthy adults. ${ }^{41,42}$

In conclusion, circulating CC16 concentrations are similar between IUGR and AGA groups, possibly suggesting that the lung immaturity and later respiratory diseases associated with the former may not be related to early CC16 deficiency. Moreover, serum CC16 concentrations increase with increasing gestational age and peak on the first day of life, possibly indicating a vital role of this protein in fetal lung maturation and extrauterine pulmonary adaptation, respectively. Future research is necessary to elucidate the role of $\mathrm{CC} 16$ in fetal lung development and postnatal respiratory adaptation in both normal and complicated pregnancies. 


\section{Acknowledgments}

No conflict of interest is declared. 


\section{References}

1. Broeckaert F, Clippe A, Knoops B, Hermans C, Bernard A. Clara cell secretory protein (CC16): features as a peripheral lung biomarker. Ann N Y Acad Sci 2000;923:68-77.

2. Bernard A, Thielemans N, Lauwerys R, Langhendries JP, Van Lierde M, Freud MM. Clara cell protein in human amniotic fluid: a potential marker of fetal lung growth. Pediatr Res 1994;36:771-775.

3. Harrod KS, Mounday AD, Stripp BR, Whitsett JA. Clara cell secretory protein decreases lung inflammation after acute virus infection. Am $\mathrm{J}$ Physiol 1998;275:L924-L930.

4. Hermans C, Knoops B, Wiedig M, Arsalane K, Toubeau G, Falmagne P, Bernard A. Clara cell protein as a marker of Clara cell damage and bronchoalveolar blood barrier permeability. Eur Respir J 1999;13:1014-1021.

5. Watson TM, Reynolds SD, Mango GW, Boe IM, Lund J, Stripp BR. Altered lung gene expression in CCSP-null mice suggests immunoregulatory roles for Clara cells. Am J Physiol Lung Cell Mol Physiol 2001;281:L1523:L1530.

6. Dierynck I, Bernard A, Roels H, De Ley M. Potent inhibition of both human interferon-gamma production and biological activity by the Clara cell protein CC16. Am J Respir Cell Moll Biol 1995;12:205-210.

7. Hermans C, Bernard A. Lung epithelium-specific proteins: characteristics and potential applications as markers. Am J Respir Crit Care Med 1999;159:646678.

8. Johnston CJ, Mango GW, Finkelstein JN, Stripp BR. Altered pulmonary response to hyperoxia in Clara cell secretory protein deficient mice. Am J Respir Cell Moll Biol 1997;17:147-155. 
9. Lomas DA, Silverman EK, Edwards LD, Miller BE, Coxson HO, Tal-Singer R; Evaluation of COPD Longitudinally to identify Predictive Surrogate Endpoints (ECLIPSE) investigators. Evaluation of serum $\mathrm{CC}-16$ as a biomarker for COPD in the ECLIPSE cohort. Thorax 2008;63:1058-1063.

10. Gioldassi XM, Papadimitriou H, Mikraki V, Karamanos NK. Clara cell secretory protein: determination of serum levels by an enzyme immunoassay and its importance as an indicator of bronchial asthma in children. J Pharm Biomed Anal 2004;34:823-826.

11. Loughran-Fowlds A, Oei J, Wang $\mathrm{H}, \mathrm{Xu} \mathrm{H}$, Wimalasundera $\mathrm{N}$, Egan $\mathrm{C}$, Henry R, Lui K. The influence of gestation and mechanical ventilation on serum clara cell secretory protein $(\mathrm{CC} 10)$ concentrations in ventilated and nonventilated newborn infants. Pediatr Res 2006;60:103-108.

12. Schrama AJ, Bernard A, Poorthuis BJ, Zwinderman AH, Berger HM, Walther FJ. Cord blood Clara cell protein CC16 predicts the development of bronchopulmonary dysplasia. Eur J Pediatr 2008;167:1305-1312.

13. Harding R, Cock ML, Louey S, Joyce BJ, Davey MG, Albuquerque CA, Hooper SB, Maritz GS. The compromised intra-uterine environment: implications for future lung health. Clin Exp Pharmacol Physiol 2000;27:965974.

14. Barker DJ, Godfrey KM, Fall C, Osmond C, Winter PD, Shaheen SO. Relation of birth weight and childhood respiratory infection to adult lung function and death from chronic obstructive airway disease. BMJ 1991;303:671-675. 
15. Rona RJ, Gulliford MC, Chinn S. Effects of Prematurity and intrauterine growth on respiratory health and lung function in childhood. BMJ 1993;306:817-820.

16. Canoy D, Pekkanen J, Elliott P, Pouta A, Laitinen J, Hartikainen AL, Zitting P, Patel S, Little MP, Jarvelin MR. Early growth and adult respiratory function in men and women followed from the fetal period to adulthood. Thorax 2007;62:396-402.

17. Cock ML, Albuquerque CA, Joyce BJ, Hooper SB, Harding R. Effects of intrauterine growth restriction on lung liquid dynamics and lung development in fetal sheep. Am J Obstet Gynecol 2001;184:209-216.

18. Maritz GS, Cock ML, Louey S, Joyce BJ, Albuquerque CA, Harding R. Effects of fetal growth restriction on lung development before and after birth: a morphometric analysis. Pediatr Pulmonol 2001;32:201-210.

19. Chen CM, Wang LF, Su B. Effects of maternal undernutrition during late gestation on the lung surfactant system and morphometry in rats. Pediatr Res 2004;56:329-335.

20. Ferguson AC. Prolonged impairment of cellular immunity in children with intrauterine growth retardation. J Pediatr 1978;93:52-56.

21. Gardosi J, Chang A, Kaylan B, Sahota D, Symonds EM. Customised antenatal growth charts. Lancet 1992;339:283-287.

22. CLASP (Collaborative Low-dose Aspirin Study in Pregnancy) Collaborative Group. CLASP: a randomised trial of low-dose aspirin for the prevention and treatment of pre-eclampsia among 9364 pregnant women. Lancet 1994:343:619-629. 
23. Burkhardt T, Schaffer L, Schneider C, Zimmermann R, Kurmanavicious J. Reference values for the weight of freshly delivered term placentas and for placental weight-birth weight ratios. Eur J Obstet Gynecol Reprod Biol 2006;128:248-252.

24. Kaminopetros P, Higueras MT, Nicolaides KH. Doppler study of uterine artery blood flow: comparison of findings in the first and second trimesters of pregnancy. Fetal Diagn Ther 1991;6:58-64.

25. Acharya G, Wilsgaard T, Berntsen GK, Maltau JM, Kiserud T. Reference ranges for serial measurements of umbilical artery Doppler indices in the second half of pregnancy. Am J Obstet Gynecol 2005;192:937-944.

26. Baschat AA, Galan HL, Bhide A, Berg C, Kush ML, Oepkes D. Doppler and biophysical assessment in growth restricted fetuses: distribution of test results. Ultrasound Obstet Gynecol 2006;27:41-47.

27. Bernard A, Marchandise FX, Depelchin S, Lauwerys R, Sibille Y. Clara cell protein in serum and bronchoalveolar lavage. Eur Respir J 1992;5:1231-1238.

28. Junor RW, Benjamin AR, Alexandrou D, Walters DV. The independence of lung liquid absorption in postnatal sheep on pulmonary blood flow, blood gases or perfussion pressure. Exp Physiol 2001;86:391-398.

29. Lassus P, Nevalainen TJ, Eskola JU, Andersson S. Clara-cell secretory protein in preterm infants' tracheal aspirates correlates with maturity and increases in infection. Pediatr Pulmonol 2000;30:466-469.

30. Levine CR, Gewolb IH, Allen K, Welch RW, Melby JM, Pollack S, Shaffer T, Pilon AL, Davis JM. The safety, pharmacokinetics, and anti-inflammatory effects of intratracheal recombinant human Clara cell protein in premature infants with respiratory distress syndrome. Pediatr Res 2005;58:15-21. 
31. Piazze JJ, Anceschi MM, Picone G, Cerekja A, La Torre R, Cosmi EV. Association between maternal-fetal Doppler velocimetry and fetal lung maturity. J Perinat Med 2003;31:484-488.

32. Ballard PL, Ballard RA. Scientific basis and therapeutic regimens for use of antenatal glucocorticoids. Am J Obstet Gynecol 1995;173:254-262.

33. Seckl JR. Glucocorticoid programming of the fetus: adult phenotypes and molecular mechanisms. Mol Cell Endocrinol 2001;185:61-71.

34. Torrance HL, Voorbij HA, Wijnberger LD, van Bel F, Visser GH. Lung maturation in small for gestational age fetuses from pregnancies complicated by placental insufficiency or maternal hypertension. Early Hum Dev 2008;84:465-469.

35. Jobe AH. Glucocorticoids, inflammation and the perinatal lung. Semin Neonatol 2001;6:331-342.

36. Sahebjami H, MacGee J. Effects of starvation on lung mechanics and biochemistry in young and old rats. J Appl Physiol 1985;58:778-784.

37. Das RM. The effects of intermittent starvation on lung development in suckling rats. Am J Pathol 1984;117:326-332.

38. Maturana A, Bernard A, Germain AM, Chau VL, Moya FR. Amniotic fluid Clara cell protein concentration in normal pregnancy, a marker of fetal airway growth or fetal lung maturation? J Perinatol 2001;21:516-520.

39. Lassus P, Nevalainen TJ, Eskola JU, Andersson S. Clara-cell secretory protein in preterm infants' tracheal aspirates correlates with maturity and increases in infection. Pediatr Pulmonol 2000;30:466-469. 
40. Helledey R, Segerstedt B, Forsberg B, Mudway I, Nordberg G, Bernard A, Blomberg A. Exploring the time dependence of serum clara cell protein as a biomarker of pulmonary injury in humans. Chest 2006;130:672-675.

41. De Jongh R, Vranken J, Kenis G, Bosmans E, Maes M, Stans G, De Ley M, Heylen R. Clara cell protein: concentrations in cerebrospinal fluid, serum and amniotic fluid. Cytokine 1998;10:441-444.

42. Nomori H, Horio H, Fuyuno G, Kobayashi R, Morigana S, Hirabayashi Y. Protein 1 (Clara cell protein) serum levels in healthy subjects and patients with bacterial pneumonia. Am J Respir Crit Care Med 1995;152:746-750. 
Table 1. Demographic data for AGA and IUGR neonates and their mothers

\begin{tabular}{|c|c|c|c|}
\hline & AGA & IUGR & $P$ \\
\hline & Mean (SD) & Mean (SD) & \\
\hline Birthweight (g) & $3280(333)$ & $2511(261)$ & $<0.001$ \\
\hline Birthweight centile & $46(24.7)$ & $2.95(1.9)$ & $<0.001$ \\
\hline Gestational age (weeks) & $39.2(0.83)$ & $38.5(1.2)$ & NS \\
\hline Gender & & & NS \\
\hline Male & $10(50 \%)$ & $7(35 \%)$ & \\
\hline Female & $10(50 \%)$ & $13(65 \%)$ & \\
\hline Maternal age (years) & $30(4.8)$ & $32.7(4.3)$ & NS \\
\hline Parity & & & NS \\
\hline Primigravida & $14(70 \%)$ & $11(55 \%)$ & \\
\hline Other & $6(30 \%)$ & $9(45 \%)$ & \\
\hline Mode of delivery & & & NS \\
\hline Vaginal & $15(75 \%)$ & $10(50 \%)$ & \\
\hline Cesarean section & $5(25 \%)$ & $10(50 \%)$ & \\
\hline
\end{tabular}

NS: non significant 
Table 2. Mean \pm standard deviation (SD) values $(\mathrm{ng} / \mathrm{ml})$ of CC16 in maternal (MS), fetal (UC), postnatal day 1 (N1) and 4 (N4) serum in appropriate for gestational age (AGA) and intrauterine growth restricted (IUGR) groups.

\begin{tabular}{|l|l|l|l|l|l|}
\hline GROUP & & MS & UC & N1 & N4 \\
\hline AGA & Mean \pm SD & $2.48 \pm 0.53$ & $2.67 \pm 0.58$ & $8.76 \pm 5.98$ & $4.43 \pm 1.97$ \\
\hline IUGR & Mean \pm SD & $2.54 \pm 0.68$ & $2.94 \pm 0.69$ & $7.39 \pm 3.70$ & $5.52 \pm 3.15$ \\
\hline
\end{tabular}


Figure legend

Fig. 1. Mean (95\% CI) serum CC16 concentrations in mothers (MS), fetuses (UC) and neonates on day $1(\mathrm{~N} 1)$ and $4(\mathrm{~N} 4)$ postpartum in appropriate for gestational age (AGA) and intrauterine growth restricted (IUGR) groups. 


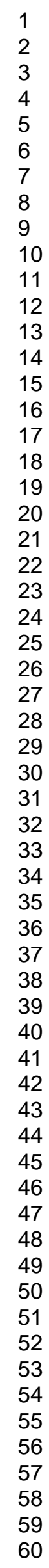

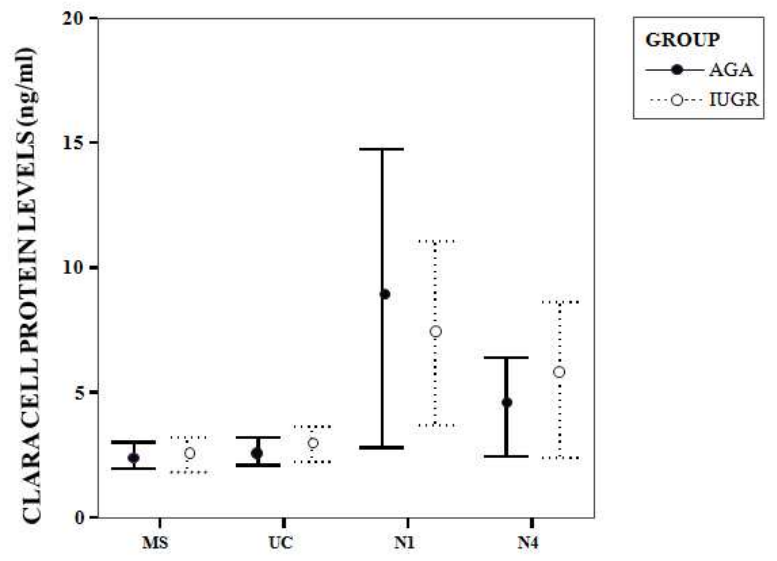

$254 \times 149 \mathrm{~mm}(96 \times 96 \mathrm{DPI})$

John Wiley \& Sons, Inc. 


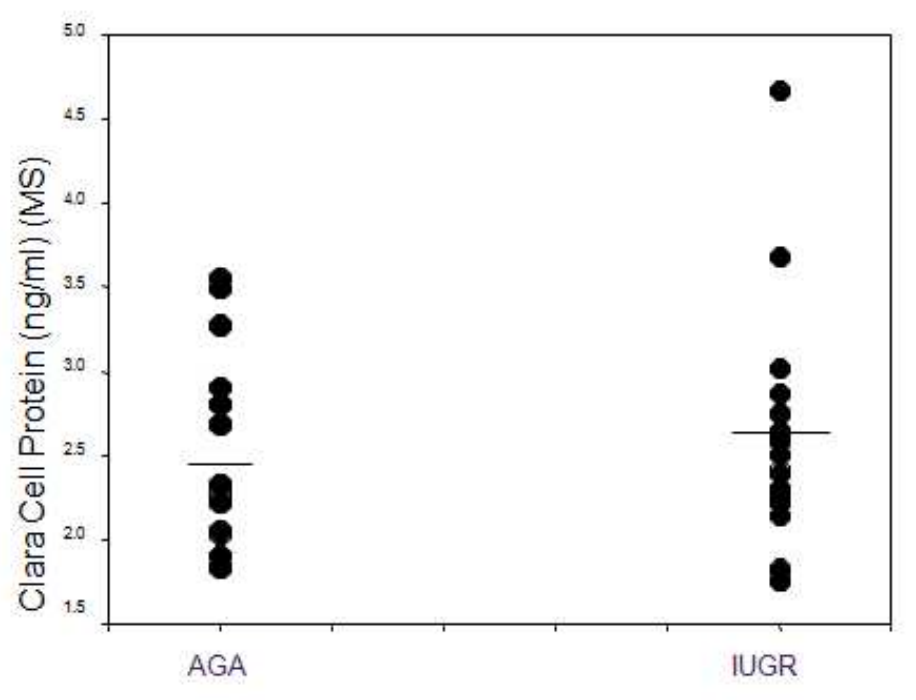

$163 \times 149 \mathrm{~mm}(96 \times 96 \mathrm{DPI})$

John Wiley \& Sons, Inc. 


1
2
3
4
5
6
7
8
9
10
11
12
13
14
15
16
17
18
19
20
21
22
23
24
25
26
27
28
29
30
31
32
33
34
35
36
37
38
39
40
41
42
43
40
45
49
50
50
51
53
55
50

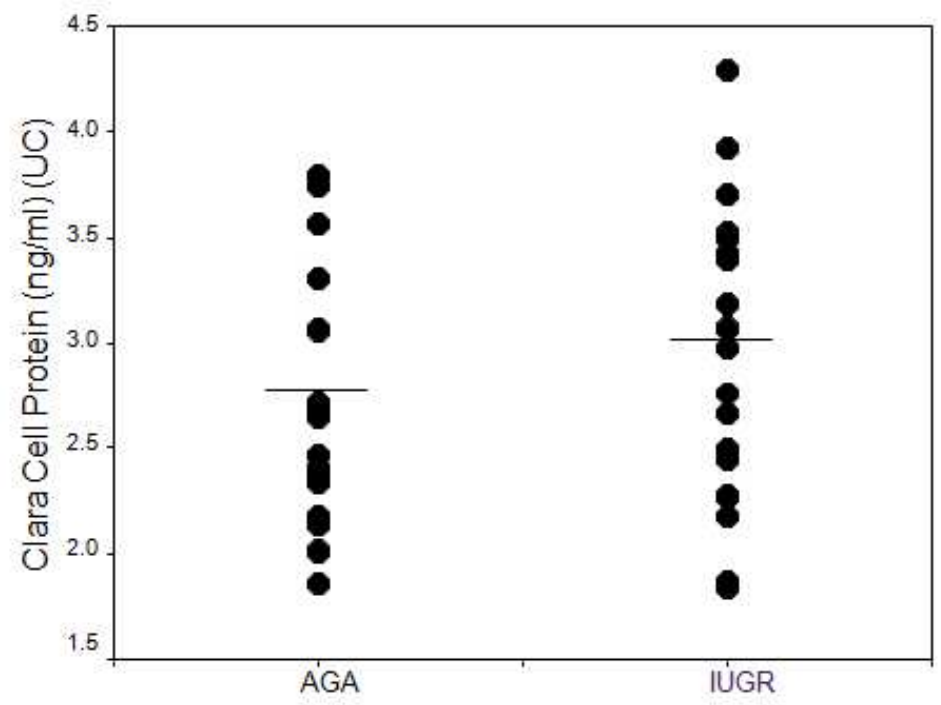

$163 \times 149 \mathrm{~mm}(96 \times 96 \mathrm{DPI})$

John Wiley \& Sons, Inc. 


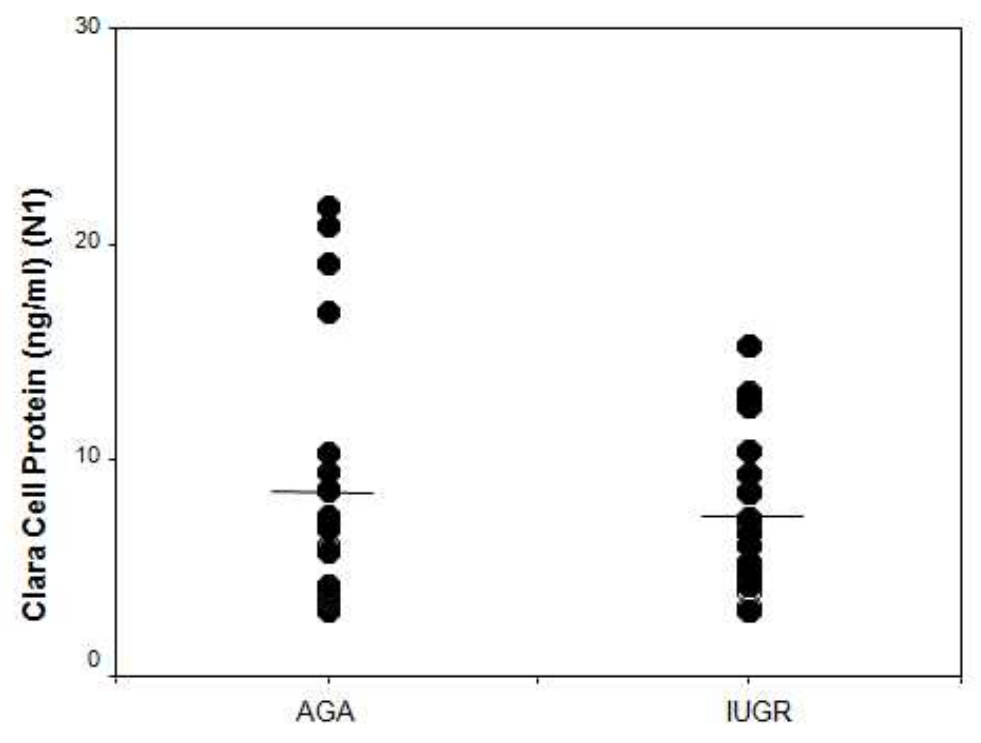

$163 \times 149 \mathrm{~mm}(96 \times 96 \mathrm{DPI})$

John Wiley \& Sons, Inc. 


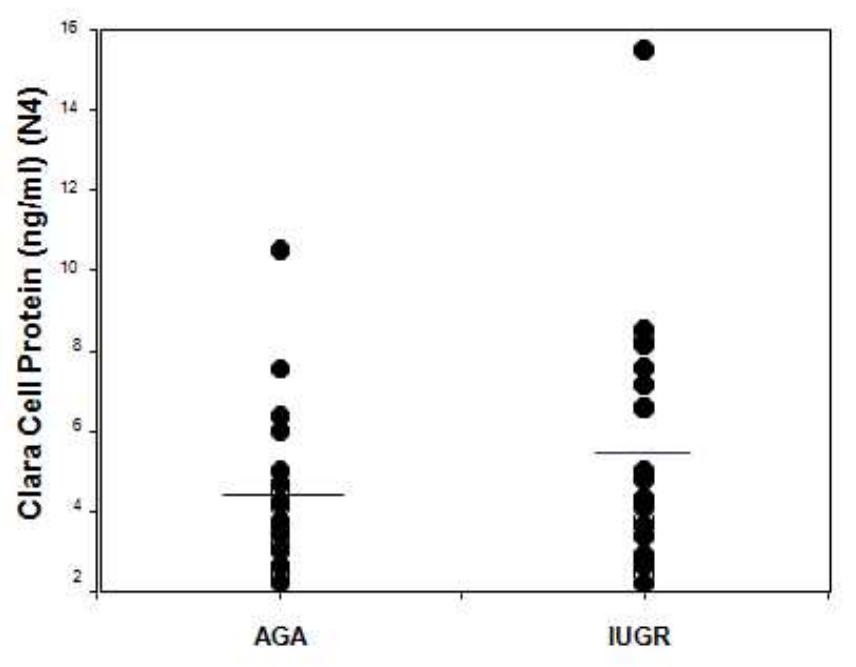

$163 \times 149 \mathrm{~mm}(96 \times 96 \mathrm{DPI})$

John Wiley \& Sons, Inc. 